\title{
Assesment of Processing Methods on the Chemical Composition of Sword Bean (Canavaliagladiata)
}

\author{
Abitogun A. $\mathrm{S}^{1}$ and Oso G. $\mathrm{K}^{2}$ \\ ${ }^{1}$ Department of Science Laboratory Technology, \\ ${ }^{2}$ Department of Hospitality Management Technology, \\ Rufus Giwa Polytechnic, P.M.B. 1019, Owo, Ondo State, Nigeria.
}

\begin{abstract}
The Canavalia glandiata used for this study was cultivated for the purpose of this study in Owo, Ondo State, Nigeria. The seed flour was subjected to different processing methods, which includes cooking, roasting and autoclaving. The effects of various processing methods on the nutritional, anti-nutritional, mineral composition and protein quality of seed flours were assessed. Again, the minerals detected in all the samples were; calcium, magnesium, potassium, sodium, iron copper, and zinc. The results in several aspects, compared favourably with those reported for many conventional edible legumes. Again, there is evidence of antinutritional factors in the seed, which were reduced by the processing methods adopted. However, the raw and processed seed flours appeared to be unsuitable as sole sources of dietary protein especially in human diets. Their incorporation in diets along with other protein resources is therefore suggested as a way of enhancing the utilization of these differently processed legume seed flours.
\end{abstract}

Key words: Canavalia glandiata, processing, proximate, amino acid, antinutritional.

\section{Introduction}

The high rate of at which world population is growing, the world food supply should grow at the same rate if not faster. The most affected countries were the developing countries. Therefore, it is essential that cheaper sources of protein and other nutrients be found. The role of legumes seed in the diets of animal and man in developing countries cannot be over- emphasized. They are rich in nutrients such as digestible protein with good array of amino acids and minerals [1]. The percentage crude proteins of most legumes vary from 20 to 50 [2] and been judged a good source of minerals. Leguminous seed have been reported to be excellent source of energy $[3,4]$ in animal and human diets. This explains why researches have been directed in exploiting the importance of these seeds in the formulation of animal and human diets.

Sword bean (Canavalia gladiata) is a tropical under-utilized food legume, wildly distributed throughout tropical Asia and tropical Africa [5]. It is usually grown as an annual crop. The leaves are shining. Pod is about $30 \mathrm{~cm}$ long and $5 \mathrm{~cm}$ wide. It contains $10-14$ seeds in a pod. Seed are elliptical and about $3 \mathrm{~cm}$ long. It has many desirable agronomic features such as high biomass production, resistance to drought, pest and disease, high fertility index and high seed productivity, $(800$ to $100 \mathrm{~kg} / \mathrm{ha}$ ) on fertile land, which enable them to grow well under tropical conditions [6]. In India, Sword bean seed are consumed by certain ethnic groups and poor village people [7]. In Asia, the young pods and seeds of Sword bean are used as green vegetable. The roasted seed are used to prepare a coffee- like drink in Latin America [8]. In Nigeria, it's usually used as an ornamental plant, grown near houses and allow to trail on the walls and trees. [9,10].However, Sword bean has potential as feeding resource that could be exploited for its forage and seeds.

There are several studies on the nutritional, anti-nutritional compositions and properties of starch extracted from the seeds; [11], little information were known about the impact of processing on the composition and nutritive quality of the seed. This study was to evaluate the chemical composition and amino acids of raw and differently processed sword bean, with a view to studying the effect of various processing methods on the chemical composition and amino acids of the seeds.

\section{Materials And Methods}

The seed of Sword bean (Canavalia gladiata ) were harvested from an experimental garden in Owo, Ondo state, Nigeria, where it was planted for the purpose of these studies. The seed was sundried for five days; about $5 \mathrm{~kg}$ of dried seed were thoroughly rinsed with distilled water before subjecting them to the different processing techniques.

\section{Processing techniques}

$5 \mathrm{~kg}$ of the seeds were soaked in water for about 2 hours and their testas peeled off manually, the dehulled seeds were sub-divided into four parts which correspond to each of the three different processing techniques: cooking, roasting, and autoclaving, while the fourth part will be untreated and consider as raw seeds. 


\section{Cooking}

The cooking was done with $100 \mathrm{ml}$ of water in aluminum pot containing $400 \mathrm{~g}$ of the seeds for 2 hours, after which the seeds became soft to touch on pressing between the thumb and fingers. Thereafter, the seeds were removed, sun-dried.

\section{Roasting}

$400 \mathrm{~g}$ of the seeds were roasted with hot plate and stirred until a characteristic brownish coloured seed was obtained which indicate complete roasting. Thereafter, the seeds were cooled.

\section{Autoclaving}

$400 \mathrm{~g}$ of the seeds were autoclaved at $121^{\circ} \mathrm{C}$ at $1.2 \mathrm{~kg} / \mathrm{cm}^{3}$ pressure for one hour and thereafter cooled and sundried. At the end of the processing, the entire processed samples and the raw sample were milled using a laboratory hammer mill. The samples were kept in airtight container for analytical works.

\section{Methods \\ Proximate analysis}

The raw and processed samples were analysed for proximate composition according to [12] methods. Crude protein was calculated by multiply the nitrogen content of the samples with the factor of 6.25. The carbohydrate content of the sample was obtained by difference in which all the proximate analysis that is moisture, content, Ash content, crude protein and fat content were added together and subtracted from 100. Each sample was analysed three times.

\section{Determination of amino acid profile}

The amino acid profile in the sample was determined using methods described by [13]. The sample was dried to constant weight, defatted, hydrolysed and evaporated in a rotary evaporator and loaded into the Technicom Sequential Multi-sample amino acid analyzer (TSM). $0.5 \mathrm{~g}$ of defatted samples was hydrolysed by refluxing for 22 hours in a heating block preset at $105^{\circ} \mathrm{C} \pm 5^{\circ} \mathrm{C}$. The hydrolysate was cooled and quantitatively transferred to $50 \mathrm{ml}$ flask and diluted with water. After filtration, a $10 \mathrm{~mL}$ aliquot of the filtrate was heated in a rotary evaporator at $40^{\circ} \mathrm{C}$ under vacuum. $10 \mathrm{~mL}$ was dispensed into the cartridge of the analyzer. The TSM analyzer is designed to separate and analyze free acidic, neutral and basic amino acids of the hydrolysate. The amino acids were calculated based on the net height of each peak produced by the chart recorder of TSM (each representing an amino acid). The half-height of the peak on the chart was found and width of the peak on the half-height was accurately measured and recorded. Approximate area of each peak was obtained by multiplying the height with the width at half-height. The norcleucine equivalent (NE) for each amino acid in the standard mixture was calculated using the formula. $\mathrm{NE}=\frac{\text { Area of norcleucine peak }}{\text { Area of amino acid }}$

\section{Determination Of Anti-Nutrients Tannin}

$0.2 \mathrm{~g}$ was weighed into $50 \mathrm{ml}$ sample bottle, $10 \mathrm{ml}$ of $70 \%$ acetone was added, and the mixture was shaken in water-bath for 2 hours at $30^{\circ} \mathrm{C}$ using Gallenkamp orbit shaker (Surrey, UK) at 120 revolutions per minute. Pigments and fat were initially removed from the samples by extracting with normal hexane containing $1 \%$ acetic acid. Thereafter, the total polyphenols (as tannin equivalent) was determined in $0.05 \mathrm{ml}$ aliquot in test tubes by the addition of distilled water to make it to $1.0 \mathrm{~mL}$, followed by the addition $0.5 \mathrm{ml}$ of the Folin Ciocaltean reagent (Sigma) and then $2.5 \mathrm{~mL}$ of the sodium carbonate solution. The tubes were vortexed and the absorbance recorded at $725 \mathrm{~nm}$ after $40 \mathrm{~min}$ as described by [14]. The amount of total polyphenols (as tannin equivalent) was calculated from the standard curve. Repeat analysis was carried out on duplicate samples.

\section{Oxalate}

$1.0 \mathrm{~g}$ of the sample was weighed into $100 \mathrm{ml}$ conical flask, $50 \mathrm{ml}$ of $1.5 \mathrm{M}$ sulphuric acid was added and it was stirred with a magnetic stirrer for 1 hour for complete extraction of oxalate from the samples. The mixture was filtered. $25 \mathrm{ml}$ of the filtrates were titrated hot against $0.1 \mathrm{M}$ potassium permanganate solution until a faint colour appeared that persisted for 35 seconds. Oxalate was calculated according to [15].

\section{Saponin}

$10 \mathrm{~g}$ of the samples were placed into $250 \mathrm{ml}$ conical flask and $100 \mathrm{ml}$ of $20 \%$ ethanol was added to it, it was heated on a hot water bath for 1 hour with constant stirring using magnetic stirrer at $55^{\circ} \mathrm{C}$. The residue was filtered and re- extracted with $20 \mathrm{ml}$ of $20 \%$ ethanol, then the extract was concentrated to $40 \mathrm{ml}$ over a water bath at about $55^{\circ} \mathrm{C}$. The concentrate was transfer into $250 \mathrm{ml}$ separating funnel and $20 \mathrm{ml}$ of diethyl ether was added and it was shaken vigorously, the ether was discarded and the aqueous layer was retained and 20ml of n-butanol 
was added in $100 \mathrm{ml}$ beaker and it was decanted. The residue was washed twice with $5 \%$ sodium chloride and it was decanted, then, the residue was dried with a known weight of $100 \mathrm{ml}$ beaker in an oven to a constant weight. Saponin was calculated according to [16].

\section{Phytate}

$4 \mathrm{~g}$ of the samples were weighed and soaked in $100 \mathrm{~cm}^{3}$ of $2 \%$ hydrochloric acid $(\mathrm{HCl})$ for three hours and it was filtered, $25 \mathrm{ml}$ of the filtrate was transferred into $100 \mathrm{ml}$ conical flask, and $5 \mathrm{ml}$ of $0.3 \mathrm{ml}$ ammonium thiocyanate $\left(\mathrm{NH}_{4} \mathrm{SCN}\right)$ was added as indicator. $50 \mathrm{ml}$ of distilled water was added for proper acidity, and it was titrated against standard Iron chloride $\left(\mathrm{FeCl}_{3}\right.$ ) which contain $0.00195 \mathrm{gm} \mathrm{Fe} / \mathrm{mL}$ until a brownish yellow colour persists for $5 \mathrm{~min}$. Phytin-phosphorous was determined and the phytin content was calculated by multiplying the value of phytin-phosphorous by 3.55 [17].

\section{Mineral Determination}

The sodium and potassium in the samples were determined by Flame photometry (Jenway Ltd, Dunmow, Essex, UK), and phosphorous by Vanado-molybdate method [12]. Calcium, Magnesium, Iron, Zinc and Copper were determined after wet digestion with a mixture of nitric, sulphuric and hydrochloric acids, using atomic adsorption spectrophotometer (Buck Scientific, East Norwalk, CT, USA).

\section{Results}

\section{Results And Discussion}

Table1: Shows the proximate composition of the differently processed sword bean in $\mathrm{g} / 100 \mathrm{~g}$

\begin{tabular}{lcccc} 
Composition & Raw & Cooked & Roasted & Autoclaved \\
\hline Crude Protein & $29.82 \pm 0.30$ & $28.71 \pm 0.30$ & $28.33 \pm 0.50$ & $29.73 \pm 0.50$ \\
Fat & $9.78 \pm 0.10$ & $8.09 \pm 0.20$ & $9.85 \pm 0.50$ & $8.37 \pm 0.10$ \\
Moisture & $8.34 \pm 0.50$ & $7.92 \pm 0.50$ & $6.58 \pm 0.10$ & $6.97 \pm 0.20$ \\
Ash & $3.93 \pm 0.50$ & $2.56 \pm 0.40$ & $3.82 \pm 0.60$ & $3.90 \pm 0.67$ \\
Crude Fibre & $7.40 \pm 0.00$ & $7.16 \pm 0.00$ & $7.36 \pm 0.30$ & $7.31 \pm 0.20$ \\
Carbohydrate & $40.73 \pm 0.20$ & $46.56 \pm 0.10$ & $44.06 \pm 0.50$ & $44.13 \pm 0.30$ \\
\hline
\end{tabular}

Mean \pm standard deviation of triplicate determination

Table 2: Shows the mineral composition of raw and differently processed Sword bean flour in $\mathrm{g} / 100 \mathrm{~g}$

\begin{tabular}{lcccc} 
Mineralsg/100g & Raw & Cooked & Roasted & Autoclaved \\
\hline & & & & 0.47 \\
Calcium & 0.52 & 0.39 & 0.36 & 0.83 \\
Sodium & 1.58 & 1.73 & 0.72 & 0.45 \\
Potassium & 0.92 & 0.40 & 0.51 & 0.34 \\
Magnesium & 0.54 & 0.28 & 0.16 & 5.08 \\
Iron mg/100g & 8.05 & 5.03 & 4.06 & 0.27 \\
Phosphorous & 0.60 & 0.40 & 0.27 & 57.02 \\
Zinc mg/100g & 72.01 & 64.01 & 57.32 & 3.01 \\
Copper mg/100g & 5.51 & 3.41 & 3.23 & \\
\hline
\end{tabular}


Table 3: Shows the Amino acid composition of protein in raw and differently processed sword bean in $\mathrm{mg} / \mathrm{g}$ protein.

\begin{tabular}{|c|c|c|c|c|}
\hline Amino Acid & Raw & Cooked & Roasted & Autoclaved \\
\hline Lysine* & 51.5 & 32.2 & 37.8 & 37.6 \\
\hline Histidine* & 22.6 & 21.3 & 21.9 & 23.2 \\
\hline Arginine & 56.2 & 40.8 & 51.2 & 47.7 \\
\hline Aspartic Acid & 56 & 72.9 & 79.2 & 79.8 \\
\hline Threonine* & 23.3 & 17.8 & 22.8 & 20 \\
\hline Serine & 32.4 & 32.1 & 39.7 & 24.3 \\
\hline Glutamic Acid & 134.1 & 113.2 & 126.6 & 101.3 \\
\hline Proline & 34.0 & 27.6 & 31.9 & 29.7 \\
\hline Glycine & 35.0 & 30.1 & 10.6 & 32.1 \\
\hline Alanine & 37.8 & 37.1 & 35.5 & 30.2 \\
\hline Cysteine & 11.9 & 7.60 & 10.6 & 9.30 \\
\hline Valine* & 34.3 & 30.2 & 32.0 & 30.2 \\
\hline Methionine* & 13.0 & 8.90 & 12.0 & 10.4 \\
\hline Isoleucine* & 35.1 & 27.0 & 30.8 & 25.7 \\
\hline Leucine* & 82.4 & 67.0 & 77.4 & 70.8 \\
\hline Tyrosine & 25.8 & 19.3 & 22.5 & 22.5 \\
\hline Phenylalanine* & 49.0 & 33.8 & 44.0 & 40.6 \\
\hline Total essential Amino Acids & 311.2 & 238.2 & 288.7 & 258.5 \\
\hline
\end{tabular}

*Essential amino acids

Table 4: shows the anti-nutritional composition of raw and differently processed Sword bean.

\begin{tabular}{lllll} 
Anti-nutritional Compositions & Raw Seeds & Cooked & Roasted & Autoclaved \\
\hline Saponin $^{1}$ & $5.20 \pm 0.05$ & $5.17 \pm 0.08$ & $4.37 \pm 0.01$ & $2.50 \pm 0.40$ \\
Tannin $^{2}$ & $0.03 \pm 0.03$ & $0.02 \pm 0.00$ & $0.02 \pm 0.0$ & $0.02 \pm 0.00$ \\
Oxalate $^{2}$ & $2.70 \pm 0.10$ & $2.02 \pm 0.06$ & $2.61 \pm 0.04$ & $0.68 \pm 0.06$ \\
Phytate $^{2}$ & $21.44 \pm 0.05$ & $12.90 \pm 0.01$ & $13.19 \pm 0.50$ & $13.43 \pm 0.04$
\end{tabular}

${ }^{1}$ Values expressed on $\mathrm{g} / 100 \mathrm{~g}$

${ }^{2}$ Values expressed on $\mathrm{mg} / \mathrm{g}$

Mean \pm standard deviation of triplicate determination

\section{Discussions}

Table 1 depicts the proximate composition of raw and differently processed sword bean flour. The crude protein ranges between $28.33 \pm 0.50$ and $29.73 \pm 0.50 \mathrm{~g} / 100 \mathrm{~g}$ compared to $29.82 \pm 0.30 \mathrm{~g} / 100 \mathrm{~g}$ obtained for raw sword bean. This implies that the processing methods employed affected the crude protein content of the seed, but to significant level. The crude protein compared favourably with values reported for some common legumes such as Pisum sativum, Phaseolus vulgaris, Cicer urietinum, Lens culinaris, different varieties of Cowpea, Cajana cajan, Pegeon peas, Bambara groundnut and some leaf vagetables [18, 19, 20, 21,22]. However, the crude protein was less than $43.1 \%$ reported for Luffa cylindrical which equally underutilized leguminous plant [19].

The values obtained for moisture content of the raw and differently processed seed flours were in the range of $6.58 \pm 0.10$ and $8.34 \pm 0.50 \mathrm{~g} / 100 \mathrm{~g}$. The moisture content though higher than those reported for gourd seed Bambcapsis glabra (3.46\%) [18], fluted pumpkin seed (5.02\%) [23] and Luffa cylindrical (5.8\%) [19,24], but still low that makes the seed not highly susceptible to microbial attack. Therefore, the seed could be kept for long period of storage and transportation. The fat content was in the range of $8.09 \pm 0.20$ and $9.85 \mathrm{~g} / 100 \mathrm{~g}$. The fat content of roasted sample was higher than the remaining samples; this might be as a result of oil cells been exposed for extraction.

The oil contents were low; this implies that the seed was not a good source of oil which means that it could not be commercially extracted and refined to edible vegetable oil. The oil contents were less than 18-20\% 
reported for some selected seeds and nuts such as Soy bean, Sunflower and Peanut $[25,26]$. However, the oil contents were higher than 1.40-4.00\% reported for processed Vigna unguiculata and $2.60 \%$ reported for Cajanus cajan [27,28]. The ash contents give an insight of the amount of inorganic content of the samples where the mineral contents could be obtained.

The values obtained for the ash content was in the range of $2.56 \pm 0.40$ and $3.93 \mathrm{~g} / 100 \mathrm{~g}$. The values of differently processed sample were less when compared with raw sample, which implies that some minerals were destroyed in the course of processing. These values obtained for ash contents were within the range 1.63 and $8.53 \mathrm{~g} / 100 \mathrm{~g}$ reported for some commonly consumed fruits and some selected varieties of Cowpeas [29,30,31]. The values obtained for ash contents were evidence that the seed could provide essential minerals needed for body metabolism.

The crude fibre contents were in the range of $7.16 \pm 0.00$ and $7.40 \pm 0.00 \mathrm{~g} / 100 \mathrm{~g}$. These values were higher than those reported for Luffa cylindrical $(2.50 \%)$, Cowpea $(2.40 \%)$, Soy bean (4.80\%), gourd seed $(2.8) ;[27,19,32]$. It suggests that the seed would provide additional dietary fibre in the diet. The carbohydrate contents of the samples were high. It was within the range of $40.73 \pm 0.20$ and $46.56 \pm 0.10 \mathrm{~g} / 100 \mathrm{~g}$. High carbohydrate feed is desirable; deficiency causes weakness and depletion of body tissues [33]. The high carbohydrate content implies that the seed might be a good source of energy. The carbohydrate contents were higher than $33.00 \%$ reported for Bombcapsis glabra [22].

The raw and differently processed sword bean contained both major and minor minerals. The major minerals include Calcium, Sodium, Potassium, Magnesium and Phosphorous, while the minor minerals include Iron, Zinc and Copper. The mineral contents were relatively low when compared with those reported for some common legumes [20,34]. The raw sample has the higher level of minerals when compared to processed bean. This implies that different processing methods reduced the level of minerals in the samples. These observations confirm the report of [35].

The low level of potassium and sodium in the processed flours makes the seed nutritionally significant, as high dietary sodium is implicated in cardiovascular and renal disorder. However, calcium, magnesium and phosphorous required for bone mineralization is relatively low in the seed flours, meaning that dietary formulae based on the seed would require their supplementation. Iron contents was relatively high, it was in the range of 4.06 and $8.05 \mathrm{mg} / 100 \mathrm{~g}$. Iron is required for blood formation and also important for normal functioning of central nervous system [36].

Table 3 depicts the result of amino acid composition of protein in raw and differently processed sword beans. The results indicated that the raw and differently processed flours contain essential amino acids. The most concentrated amino acid in all the samples was glutamine; it was within the range value of 101.3 and $134.1 \mathrm{mg} / 100 \mathrm{~g}$. Next to glutamine was Leucine* an essential amino acid with the range values of 67.0 and $82.4 \mathrm{mg} / 100 \mathrm{~g}$. The level of arginine was high; noting that arginine was an essential amino acid for the growth of children [37]. The amino acids profiles in raw sample were higher than differently processed samples. This implies that different processing methods reduced the amino acid profile of the seed flour. However, the seed is of dietary important. Comparison between the amino acid content and the [38] amino acid reference values shows that leucine, lysine, phenylalanine, isoleusine and valine in the seed were on the high side of the recommended range of amino acid requirement for infants and significantly higher than the values recommended for pre-school children. The value range of 8.90 and $13.00 \mathrm{mg} / 100 \mathrm{~g}$ obtained for Methionine was higher than $3.2 \mathrm{mg} / 100 \mathrm{~g}$ reported for Cajnus cajan $[27,38]$.

Table 4 gives the anti-nutritional composition of raw and differently processed sword bean. The antinutrients detected in all the samples include saponin, tannin, oxalate, phytate, and alkaloid. Tannin ranged between 0.02 and $0.03 \mathrm{mg} / 100 \mathrm{~g}$ in the studied samples. Tannin is known to inhibit the activities of digestive enzymes and nutritional effects of tannin are mainly related their interaction with protein. The values reported for tannin were very low to be nutritional importance. The values obtained were low to be of any nutritional importance. These values were however low when compared to $13.3 \mathrm{mg} / \mathrm{g}, 19.1 \mathrm{mg} / \mathrm{g}$ and $99.2 \mathrm{mg} / \mathrm{g}$ tannin reported for cashew nut, fluted pumpkin and raw breadnut respectively [39]. Studies on rats, chicks and livestock revealed that high tannin in diet adversely affects digestibility of protein and carbohydrates, thereby, reducing growth, feeding efficiency, metabolizable energy and bioavailability of amino acids [40].

The values obtained for phytate ranged between $21.44 \pm 0.05$ and $12.90 \pm 0.01 \mathrm{mg} / \mathrm{g}$, from the result, processing methods applied reduces the level of phytate, cooking was the most effective method that reduces the phytate level. This confirms the previous reports of [41]. The value obtained for raw sample was higher than $18.5 \mathrm{mg} / 100 \mathrm{~g}$ reported for Canavalia ensiformis [42]. Phytate was reported as decreasing the bioavailability of minerals in monogastric animals [40] if consumed over a long period of time, its presence in food is also beneficial because it have positive nutritional role as an anti-oxidant and anti-cancer agent [43].

Oxalate is a concern because of its negative effect on mineral availability. High oxalate diet increases the risk of renal calcium absorption and has been found to be as a source of kidney stone [44]. The values obtained for oxalate were in the range of $0.68 \pm 0.06$ and $2.7 \mathrm{mg} / 100 \mathrm{~g}$. However, the level of oxalate in the 
samples might not play important role in their nutritive values. Of all the processing methods, autoclaving was more effective in reducing the level of oxalate.

Saponin ranged from $2.50 \pm 0.40$ to $5.20 \pm 0.05 \mathrm{~g} / 100 \mathrm{~g}$. Saponins are suspected to exhibit a wide spectrum of biological activity as antifungal and antibacterial agents. Saponin rich food may also contribute to lowering of blood cholesterol and inhibits the growth of cancer cell. Saponin acts by binding with bile acids and cholesterol, so it was reported that this chemical potentially has the ability to clean or purge this fatty compound from body, thus, lowering the blood cholesterol level [45].

\section{Conclusion}

The assessment indicates that these seeds have potential for human and animal feed judging from their proximate composition, mineral contents and amino acid profile of the seed. The results in several aspects, compared favourably with those reported for many conventional edible legumes. Again, there is evidence of anti-nutritional factors in the seed, which were reduced by the processing methods adopted. However, the raw and processed seed flours appeared to be unsuitable as sole sources of dietary protein especially in human diets. Their incorporation in diets along with other protein resources is therefore suggested as a way of enhancing the utilization of these differently processed legume seed flours.

\section{References}

[1]. A. D. Ologhobo, Biochemical and Nutritional studies of cowpeas and Lima bean with particular reference to some inherent antinutritional factors, doctoral diss., University of Ibadan, Ibadan, Nigeria, 1980.

[2]. B, Mackinder. R. Pasquest. Polhell and B.Vardcourt,(2001). leguminosae (papilinoideae: phaseoleae). Plenum press. United Kingdom, 2001, 261.

[3]. R.R. Del Rosario., Y, Lozano., M.G,Noel, The chemical and bio-chemical composition of legume seeds, 2, Cowpea. Philippine Agriculturist, 64,1981, 49-57.

[4]. D. B. Oke, O.O. Tewe and B.L. Fatuga, The nutritional composition of some Cowpea varieties. Nigeria Journal of Animal Production. 22, (1), 1995, 32-36.

[5]. C.H. Bosch, Canavalia gladiata (Jacq) DC. Plant resources of tropical Africa

[6]. \{internet\}http:// www. Prota.org, 2004.

[7]. ILDIS,World databse of legumes; International legunme. Database and Information services (Internet) http://www. Ilolis.org, 2002.

[8]. M. Pugalenthi and V. Vadivel, Nutritional evaluation on the effect of processing mathods on antinutritional factors of sword bean (Canavalia gladiata (Jacq) DC.j. Food sci. Technol, 42, 2005, 510-516.

[9]. V. Vadivel., K. Janardhanan., K. Vijayakumri, Divercity in sword bean_(Canavalia gladiata (Jacq) DC. collected from Tamil Nadu, India. Genet. Res. Crop Evol, 45, 1998, 63-68.

[10]. J. Smartt, Grain legumes: evaluation and the effect of processing press, United kingdom. 1990, 379.

[11]. V. Vaikundaraman and J. Karnam, The nutritional and antinutritional attributes of sword bean [(Canavalia gladiata (Jacq) DC]: an under- utilized tribal pulse from south India.

[12]. O.A. Kayode., T.A Afolabi., B. I. Olu-Oluwa, Functional, physicochemical and retrogradation properties of sword bean (Canavalia glandiata) acytylated and oxidized starches, 65, 2006, 93-101.

[13]. A.O.A.C. Official Method of Analysis of the Association of Analytical Chemist Washington D. C. USA. $1992,1250-1255$.

[14]. D. H. Speckman, E. H Stein and V.S Moore, Automatic recording apparatus for use in the chromatography of amino acids. Analytical Chemistry. 30: 1958, 1191.

[15]. A.O.S. Makkar., A.V. Goodchild, Quantification of tannins. A laboratory manual. International Centre for Agriculture Research in the Dry Areas (ICARDA) Aleppo, syria IV 1996, + 25

[16]. RA Day, AL Underwood. Qualitative Analysis. 5th Ed. New Delhi, India: Prentice-Hall Publications; $1986,701$.

[17]. B.O Obadoni and P.O. Chuko, Phytochemical studies and comparative efficacy of the crude extract of some Haemostatics plants in Edo and Delta states of Nigeria. Global Journal of Pure and Applied Sci, 8, (2) 2002, 203-208.

[18]. S.M, Young and J.S. Greaves, Influence of variety and treatment on phytin contents of wheat. Food Res., 5: 1940, 103-105.

[19]. J.B Harborne, Phytochemical methods, London. Chapman and Hall, Ltd. 1973. 49-188.

[20]. B.Y Olaofe., Okiribit., M.O. Aremu, Chemical evaluation of nutritive value of smooth Luffa (Luffa cylindrica) seed kernel, ELEAF Che. 7 (10), 34444-3452.

[21]. D.B. Oke, O.O Tewe., B.L Fatuga. The nutrient composition of some cowpea varieties. Nigerian Journal of Animal Production 22, (1) $1995,32-36$

[22]. M.O. Aremu., O, Olaofe., E.T Akintoye, Parkistan Journal of Nutriton, 5 (1), 2006, 34-38.

[23]. S.M. Odetokun., A.F. Ayesanmi, Manihot glaziovii seed protein; chemical evaluation of quality of protein L.A. Rivista Italiana delle Sostanze Grasse LXV-GIUGNO, 1998, 299-300.

[24]. GEA Costa., KS Queiroz-Monici., SMP Reis and AC Oliveira, Chemical composition, dietary fiber and resistant starch content of raw, cooked pea, common bean and lentil legumes. Food Chem 94, 2006, 327-330.

[25]. O. Olaofe., E.T Akintayo., E.I Adeyeye., H.O Adubiaro, Proximate composition and functional properties of Bulma cotton (Bambcapsis glabra) seed. Egypt Journal of Food Science, 34,2006, 81-90.

[26]. J.E Aisegbu, Some biochemical evaluation of fluted pumpkin seed. J. Sci. Food Agric., 40, 1987, 151-155

[27]. A.S Abitogun., A.O Ashogbon, Nutritional assessment and chemical composition of raw and defatted Luffa cylindrical seed flour. Ethnobotanical leaflets 14, 2010, 225-235.

[28]. A. S. Abitogun and A. A. Oshodi, Effects of degumming and bleaching on the Physicochemical parameters of crude Sunflower oil. J. Chem. Soc. Nigeria. 35, (2), 2010, 57-61.

[29]. D. K. Salunkhe, R. N. Chavanand and S. S. Adsule-Kadam, World Oilseeds, Chemistry Technology and Utilization (Van Nortrand Rainhold, New York, 1992).

[30]. A.A Oshodi, O Olaofe, and GM Hall GM, Amino acid, Fatty acid and mineral composition of pigeon pea . J of food science and nutrition 43, 1993, 187-191.

[31]. A. S. Abitogun, O. A. Seyifunmi, V. E. Adebote and A.C. Omosheyin, Nutritional and chemical composition of Pigeon Pea (Cajanus cajan) flour and oil. Journal of Environmental Planning and Development, 2, (1), 2010, 33-36. 
[32]. EA Oluyemi, AA Akinlua, AA Adenuga, MA Adebayo. Mineral contents of some commonly consumed Nigeria foods. Sci focus. 11(1), 2006, 153-157.

[33]. J.T Ayodele,. O.A Alao., T.O. Olagbemiro, Chemical composition of Serculia setigera. Trop. J. Anim. Sci. 3, (2): 2000, 69-67.

[34]. CFM Mbofung., YN Njintang., KW Waldron, Functional properties of cowpea-soy-dry red beans composite flour paste and sensorial characteristics of akara (deep fat fried food); Jour. of Food Science 34, 2002. 207-214.

[35]. E.T. Akintayo., E.A. Adebayo., L.A. Arogundade, Chmical composition physicochemical properties of akee (Bilphia saphida) pulp and seed flour, Food Chemistry 77, 2002, 333-336.

[36]. M.M Barker. Nutrition and Dietetics for Health Care. $9^{\text {th }}$ Edn. Chuchill Livingstone, New York, N.Y. 1996, 92-101.

[37]. V.A Aletor and O.O. Aladetimi, compositional evaluation of some Cowpea varieties and under- utilized edible legumes grown in Nigeria. Die Nahrung-Food 33, (10) 1989, 999-1007.

[38]. D.F Apata and A,D, Ologholo, Some aspect of the biochemistry and nutritive value of African yam bean (Sphenosity stenocarpa). Food Chemistry, 36, 1990, 27-280.

[39]. MYG Shills and V.R In: Nieman, DC Butterworth, D.E. and Nieman, C.N. (eds). Nutrition, WmC, Brown Publishers, Dubugue, USA, 1992, 279-282.

[40]. NRC (National Research Council) Recommended Dietary Allowances. $10^{\text {th }}$ edn. National Academic Press, Washington DC, USA, 1989.

[41]. FAO/WHO Protein quality evaluation report of joint FAO/WHO expert consultative FAO. Food and Nutrition 1991

[42]. T.N Fagbemi, A.A Oshodi, K.O Ipinmoroti (2005). Processing Effects on some Antinutional factor and in vitro multienzyme protein digestibility of three tropical seeds: Breadnut, Cashewnut and fluted pumpkin. Pak. J .nutri. 4(4):2005, 250-256.

[43]. M.O Bello, O.S Falade, SRA Adewusi and N.O Olawore. Studies on the chemical compositions and antinutriens of some lesser known Nigeria fruits. J. of Biotechnology 7. (22), 2005, 3972 -3979.

[44]. S.S Gad., M.S. Mohamed., M.E. El-Zalaki., S.Z. Mohassed, Effect of processing on phosphorous and phytic acid contents of some Egytian Varieties of legume. Food Chemistry, 8, 1982, 11-19.

[45]. J.O Agbede and V.A. Aletor, Studies of the chemical composition and protein quality evaluation of differently processed Canavalia ensiformis and Mucuna pruriens seed flours. J. Food Comp. Analy., 18: 2005, 89-103.

[46]. U Schlemmer, W Frolich, RM Prieto, F Greases, Phytate in foodand significance for humans; food sources, intake, processing, bioavailability, protective role and analysis. Mol. Nutri. Res, suppl 2, 2009, s 330-375.

[47]. LK Massay., H Roman-Smith., RA Sutton. Effect if dietary oxalate and calcium on urinary oxalate and risk of formation of calcium oxalate kidney stones, J. Am. Diet Assoc. 93, (8) 1993, 901-6.

[48]. J. Shi, K Arunasalam, D Yeung, Y Kakuda., Mittal., Y Jiang. Saponin from edible legumes Chemistry, processing and health benefit. J. Med. Food, 7, (1) 67-68. 